\title{
ASPEK HUKUM TERHADAP PERUSAHAAN PINJAMAN ONLINE ILEGAL MENURUT SYSTEM HUKUM DI INDONESIA
}

\author{
Ayu Dian Ningtias, SH.MH, Suisno, SH.MHum, Dhevi Nayasari S, SH,MM \\ ayudian.ningtias@yahoo.com, susisno72@gmail.com, Dhevinss@gmail.com
}

Univeristas Islam Lamongan

\begin{abstract}
Abstraksi
Layanan pinjam meminjam uang berbasis teknologi informasi sendiri diatur dalam Peraturan Otoritas Jasa Keuangan Nomor 77/POJK.01/2016 Tahun 2016 tentang Layanan Pinjam Meminjam Uang Berbasis Teknologi Informasi ("POJK 77/2016"). Pasal 1 angka 3 POJK 77/2016 menerangkan bahwa layanan pinjam meminjam uang berbasis teknologi informasi adalah penyelenggaraan layanan jasa keuangan untuk mempertemukan pemberi pinjaman dengan penerima pinjaman dalam rangka melakukan perjanjian pinjam meminjam dalam mata uang rupiah secara langsung melalui sistem elektronik dengan menggunakan jaringan internet.

Kata Kunci: Teknologi Informasi , Pinjaman Online Ilegal, Aspek Hokum Pidana
\end{abstract}

\section{PENDAHULUAN}

Financial Technology yaitu jika diartikan kedalam bahasa Indonesia yaitu teknologi keuangan. Secara sederhana, Fintech memiliki arti sebagai pemanfaatan dari perkembangan teknologi informasi untuk meningkatkan layanan industry dibidang keuangan. Definisi lainnya adalah variasi model bisnis dan perkembangan teknologi yang memiliki potensi untuk meningkatkan industri layanan keuangan. ${ }^{1}$

Fintech merupakan penerapan dari peningkatan layanan dalam bidang jasa perbankan dan keuangan yang umumnya dilakukan oleh rintisan perusahaan (startup) dengan pemanfaatn teknologi software,

(Jakarta: Departemen Perlindungan Konsumen OJK, 2017) h.8. 
internet, komunikasi dan komputasi

terkini. Konsep ini mengadaptasi perkembangan teknologi yang dipadukan dengan bidang finansial sehingga bisa menghadirkan proses transaksi keuangan yang lebih praktis, aman serta moderen. ${ }^{2}$

\section{Semakin berkembangnya} teknologi, jenis-jenis Fintech semakin beragam, diantaranya seperti inovasi teknologi finansial terkait pembayaran dan transfer, lembaga jasa keuangan, dan perusahaan start-up Fintech yang menggunakan teknologi baru untuk memberikan layanan yang lebih cepat, murah dan nyaman. Menurut bank Indonesia jenis Fntech yang paling diminati yakni Peer to Peer $(P 2 P)$ Lending karena banyak keuntungan bagi penyedia jasa keungan, yaitu: ${ }^{2}$

1. Sudah terdaftar dalam OJK

2. Memberikan pinjaman dengan cepat dan mudah

2 Djoni S. Gozali dan Rachmadi Usman, Hukum Perbankan, cet. II, Sinar Grafika, Jakarta, 2012, h. 286.
3. Mendiversifikasi investasi

4. Bunga yang tinggi

Kehadiran fintech merupakan soslusi bagi masyarakat yang belum tersentuh oleh layanan jasa perbankan sehingga menjadi solusi alternatif untuk mendatangkan kemudahan bagi masyarakat untuk mendapatkan layanan transaksi keuangan yang mudah dan cepat. $^{3}$

Di tahun 2019 per tanggal 15 Febuari 2019 yang diberitakan oleh Liputan6.com, OJK mengeluarkan daftar 231 penyelenggara layanan pinjam meiminjam uang berbasis teknologi informasi Fintech Peer to Peer Lending yang tidak memiliki izin. Aktifitas 231 Fintech Peer to Peer ilegal ini telah resmi diberhentikan oleh tim Satuan Tugas Penanganan Dugaan Tindakan Melawan Hukum di Bidang Penghimpunan Dana Masyarakat dan Pengolaan Investasi atau disingkat

${ }^{3}$ Ibid., h. 26. 
Jurnal Independent Fakultas Hukum

Satgas Waspada Investasi. ${ }^{4}$ Pada

tanggal 4 Desember 2019 Satgas

Waspada Investasi kembali

menemukan 125 entitas yang

melakukan kegiatan belum mempunyai

izin atau terdaftar dalam OJK.

\section{METODE PENELITIAN}

Melalui penelitian yuridis normatif akan diteliti tentang bentuk perlindungan anak korban perkosaan dan bagaimana perbedaaan anatara rehabilitasi dan restitusi, untuk itu akan dianalisa berdasarkan teori-teori hukum, prinsipprinsip hukum, doktrin-doktrin hukum seta peraturan perundang-undangan yang terkait. Dalam penelitian ini menggunakan Pendekatan perundang-undangan (statute approach), dan Pendekatan konseptual (conceptual approach).

Pendekatan perundangan-undangan (statute approach) diperlukan guna mengkaji lebih lanjut mengenai dasar hukum. Pendekatan perundang-undangan dilakukan dengan menelaah semua undangundang dan regulasi yang bersangkut paut dengan isu hukum. ${ }^{5}$ Pendekatan perundang-

Ayu Lestari Wahyu Puranidhi 2019, "pinjaman online ilegal dari OJK”,https://www.liputan6.com/me/ayu.pu ranidhi, Jakarta.

${ }^{5}$ ibid. undangan ini dimaksudkan untuk mengkaji dan menganalisis terhadap peraturan perundang-undangan yang berkaitan dengan isu hukum terkait. ${ }^{6}$

III. ASPEK HUKUM TERHADAP PERUSAHAAN PINJAMAN ONLINE ILEGAL MENURUT SYSTEM HUKUM DI INDONESIA

Pesatnya perkembangan teknologi finansial yang ada di Indonesia perlu untuk membuat sebuah aturan untuk mengatur kegiatan bisnis peminjaman online atau teknologi finansial karena dirasa rawan akan adanya dampak bagi masyarakat yang menggunakan jasa teknologi finansial. Maka dari itu Bank Indonesia (BI) mengeluarkan peraturan Bank Indonesia Nomor 19 Tahun 2017 tentang Penyelenggaraan Teknologi Finansial.

Istilah fintech yang merupakan akronim dari financial technology sudah tak asing lagi di dunia bisnis Indonesia beberapa tahun belakangan. Salah satu definisi fintech dari sebuah pusat penelitian digital di Irlandia adalah

${ }^{6}$ Peter Mahmud Marzuki, Metode Penelitian Hukum. Kencana, Jakarta 2005, h.15 
"innovation in financial services" atau inovasi dalam layanan keuangan. ${ }^{7}$

Oleh karena itu adanya peraturan tersebut penyelenggara Teknologi Finansial harus diawasi mengenai penyelenggaraan pemrosesan transaksi pembayaran agar tidak terjadi kelalaian penyelengaraan kegiatan teknologi finansial seperti belum memiliki izin, melakukan pembocoran atau penyalahgunaan data pribadi, dan melakukan kekerasan saat pengihan hutang

Dalam Pasal 1 Peraturan Bank Indonesia (PBI) Nomor 19 tahun 2017 tentang Penyelenggaraan Teknologi Finansial definisi teknologi finansial atau Fintech adalah

“Teknologi Finansial adalah penggunaan teknologi dalam sistem keuangan yang menghasilkan produk, layanan, teknologi, dan/atau model bisnis baru serta dapat berdampak pada stabilitas moneter, stabilitas sistem keuangan, dan/atau efisiensi, kelancaran, keamanan, dan keandalan sistem pembayaran"

Peraturan Bank Indonesia Nomor 19/12/ PBI 2017 tentang teknologi finansial mendefinisikan teknologi finansial sebagai penggunaan teknologi

${ }^{7}$ https://www.hukumonline.com/berita/baca/ lt5a97b394460ec/aspek-hukum-fintech-diindonesia- yang-wajib-diketahui-lawyer/. dalam sistem keuangan yang menghasilkan produk layanan, teknologi, dan/atau model bisnis baru serta dapat berdampak pada stabilitas moneter, stabilitas sistem keuangan, dan/atau efisiensi, kelancaran keamanan dan keandalan sistem pembayaran. Pasal 3 Peraturan Bank Indonesia Nomor 19/12/ PBI 2017 membagi teknologi finansial menjadi lima hal,yaitu:

1. Sistem pembayaran;

2. Pendukung pasar;

3. Manajemen investasi dan manajemen risiko;

4. Pinjaman, pembiayaan, dan penyediaan modal; dan

5. Jasa finansial lainnya.

Financial Technology yang selanjutnya akan disebut fintech adalah inovasi dalam bidang keuangan yang membuat kegiatan usaha menjadi lebih efisien dan mudah dilakukan di mana pun. Jaringan internet yang semakin kuat dan pemikiran masyarakat yang mulai terbuka di era digital ini mempermudah perkembangan fintech.

Berdasarkan pasal 3 ayat 2 Peraturan

Bank Indonesia Nomor 19/12/ PBI 2017

tentang teknologi finansial bahwa

teknologi finansial ini harus memenuhi

kriteria yaitu:

1. Bersifat inovatif;

2. Dapat berdampak pada produk, layanan, teknologi, 
dan/atau model bisnis finansial yang telah eksis;

3. Dapat memberikan manfaat bagi masyarakat;

4. Dapat digunakan secara luas; dan

5. Kriteria lain yang ditetapkan oleh Bank Indonesia. Sedangkan menurut

Peraturan Bank Indonesia Nomor 19/12/PBI/2017 pada Pasal 3 bahwa teknologi finansial di kategorikan ke dalam lima macam tidak hanya layanan pinjam meminjam yang berbasis teknologi. Pada Peraturan Bank Indonesia Nomor 19/12/PBI/2017 ini juga ditambah dengan Peraturan Anggota Dewan Gubernur yang berfungsi sebagai peraturan tambahan untuk menjelaskan beberapa hal secara lebih rinci seperti yang tertera pada Pasal 7 mengenai tata cara pendaftaran, tertera pada ayat 4 yang berbunyi sebagai berikut:

$\begin{array}{lrr}\text { "ketentuan lebih } & \text { lanjut } \\ \text { mengenai } & \text { tata } & \text { cara } \\ \text { pendaftaran diatur } & \text { dalam } \\ \text { Peraturan Anggota } & \text { Dewan } \\ \text { Gubernur." }\end{array}$

Dengan munculnya kedua aturan ini bisa dikatakan bahwa seluruh perusahaan Financial Technology sudah mempunyai sebuah payung hukum untuk melindungi perusahaan tersebut dan sudah jelas juga bahwa hanya perusahaan yang berbadan hukum saja yang dapat mendaftarkan dirinya sebagai penyelenggara teknologi finansial, tetapi apabila perusahaan tersebut ingin menyelenggarakan sebuah layanan pinjam meminjam uang berbasis teknologi informasi maka harus berbentuk Perseroan Terbatas atau Koperasi seperti yang diatur dalam POJK Nomor 77 Pasal 2.

Bank Indonesia (BI) sesuai dengan kewenangannya yang mengatur dan mengawasi industri jasa keuangan telah menerbitkan beberapa regulasi untuk mengatur fintech yang sedang berkembang pesat pada saat ini. Berikut adalah beberapa regulasi tersebut :

1. Peraturan Bank Indonesia (PBI) Nomor 18/40/PBI/2016 tentang Penyelenggaraan Pemrosesan Transaksi Pembayaran (PTP).

Sebagaimana dilansir dari laman resminya, terbitnya PBI Nomor 18/40/PBI/2016 ini bertujuan untuk memenuhi kebutuhan masyarakat, termasuk di bidang jasa sistem pembayaran, baik dari sisi instrumen, penyelenggara, mekanisme maupun infrastruktur penyelenggaraan pemrosesan transaksi pembayaran. Cakupan dalam PBI ini meliputi penyelenggaraan dalam pemrossan transaksi pembayaran, perizinan dan persetujuan dalam penyelenggaraan pemrosesan transaksi pembayaran, kewajiban dalam penyelenggaraan 
pemrosesan transaksi pembayaran, laporan, peralihan izin penyelenggara jasa sistem pembayaran dan pengawasan, larangan, serta sanksi.

2. Peraturan Bank Indonesia (PBI) Nomor 19/12/PBI/2017 tentang Penyelenggaraan Teknologi Finansial

Perkembangan fintech di Indonesia tumbuh begitu cepat sehingga dikhawatirkan akan berdampak buruk pada penyelenggaraannya. Untuk itu, BI menerbitkan PBI Nomor 19/12/PBI/2017 sebagai payung hukum demi menjaga kestabilan sistem keuangan di Indonesia tersebut. Terbitnya PBI Nomor 19/12/PBI/2017 ini bertujuan untuk mendukung terciptanya stabilitas moneter, stabilitas sistem keuangan, serta sistem pembayaran yang efisien, lancar, aman, dan andal untuk mendukung pertumbuhan ekonomi nasional yang berkelanjutan dan inklusif dengan menerapkan prinsip perlindungan konsumen serta manajemen risiko dan kehati-hatian.

Di samping itu, BI juga menerbitkan ketentuan pelaksanaan PBI penyelenggaraan Teknologi Finansial diatur dalam Peraturan Anggota Dewan Gubernur (PADG) No. 19/14/PDAG/2017 tentang Ruang Uji Coba Terbatas (Regulatory Sandbox) Teknologi Finansial dan PADG No.
19/15/PADG/2017 tentang Tata Cara Pendaftaran, Penyampaian Informasi, dan Pemantauan Penyelenggara Teknologi Finansial.

Diharapkan dengan adanya peraturan dari Bank Indonesia terkait dengan penyelenggaraan teknologi finansial ini dapat memberikan pemahaman bagi pelaku bisnis Teknologi finansial agar tidak melakukan kegiatan bisnis Fintech yang ilegal dan merugikan pihak lain.

Dalam perjalanan industri Teknologi Finansial di Indonesia masih banyaknya kegiatan usaha ini yang masih belum terdaftar dalam Otoritas Jasa Keuangan (OJK) dan membuat banyak kasus yang yang berhubungan dengan sektor peminjaman uang online, seperti melakan pembocoran data pribadi, melakukan kekerasan saat penigahan hutang dan memberikan bunga yang terlalu tinggi.

Oleh sebab itu OJK mengeluarkan peraturan terkait dengan industri teknologi finansial POJK Nomor 77 Tahun 2016 tentang Layanan Pinjam Meminjam Uang Berbasis Teknologi Informasi.

Dalam Pasal 1 POJK Nomor 77/POJK.01/2016 pengertian OJK adalah sebagai berikut:

"Otoritas Jasa Keuangan yang selanjutnya disingkat OJK adalah lembaga yang independen, yang 
mempunyai fungsi, tugas, dan wewenang pengaturan, pengawasan, pemeriksaan, dan penyidikan sebagaimana dimaksud dalam UndangUndang Nomor 21 Tahun 2011 tentang Otoritas Jasa Keuangan".

Dalam Pasal 3 POJK Nomor 77/POJK.01/2016 pengertian Layanan Pinjam Meminjam Uang Berbasis Teknologi Informasi adalah sebagai berikut :

"Layanan Pinjam Meminjam Uang Berbasis Teknologi Informasi adalah penyelenggaraan layanan jasa keuangan untuk mempertemukan pemberi pinjaman dengan penerima pinjaman dalam rangka melakukan perjanjian pinjam meminjam dalam mata uang rupiah".

Dalam kegiatan penyelenggaraan layanan pinjam meminjam uang berbasis teknologi penyelenggara wajib mengajukan permohonan izin untuk mendirikan kegiatan usaha ini kepada OJK berdasarakan aturan POJK pasal 7 Nomor 77/POJK.01/2016 sebagai berikut:

"Penyelenggara wajib mengajukan pendaftaran dan perizinan kepada OJK”

Berdasarkan peraturan tersebut jika ada penyelenggara pinjam meminjam berbasis teknologi yang tidak mengantongi izin dari OJK maka akan diberlakukan sanksi "pencabutan tanda daftar atau perizinan aplikasi pinjaman online di jejaring internet”.

\section{PENUTUP}

Layanan pinjam meminjam uang berbasis teknologi informasi sendiri diatur dalam Peraturan Otoritas Jasa Keuangan Nomor 77/POJK.01/2016 Tahun 2016 tentang Layanan Pinjam Meminjam Uang Berbasis Teknologi Informasi ("POJK 77/2016”). Pasal 1 angka 3 POJK 77/2016 menerangkan bahwa layanan pinjam meminjam uang berbasis teknologi informasi adalah penyelenggaraan layanan jasa keuangan untuk mempertemukan pemberi pinjaman dengan penerima pinjaman dalam rangka melakukan perjanjian pinjam meminjam dalam mata uang rupiah secara langsung melalui sistem elektronik dengan menggunakan jaringan internet.

Adapun penyelenggara layanan pinjam meminjam uang berbasis teknologi informasi ("penyelenggara") adalah badan hukum Indonesia yang menyediakan, mengelola, dan mengoperasikan layanan pinjam meminjam uang berbasis teknologi informasi. $^{8}$

8 R. Subekti. Hukum Perjanjian. Jakarta: Intermasa, 2014. h.14 
Selain itu, pemberi pinjaman adalah orang, badan hukum, dan/atau badan usaha yang mempunyai piutang karena perjanjian layanan pinjam meminjam uang berbasis teknologi informasi. Sementara, penerima pinjaman adalah orang dan/atau badan hukum yang mempunyai utang karena perjanjian layanan pinjam meminjam uang berbasis teknologi informasi.

Secara khusus, Pasal 18 POJK 77/2016 menerangkan bahwa: Perjanjian pelaksanaan Layanan Pinjam Meminjam Uang Berbasis Teknologi Informasi meliputi; perjanjian antara Penyelenggara dengan Pemberi Pinjaman; dan perjanjian antara Pemberi Pinjaman dengan Penerima Pinjaman.

Selain itu, penyelenggara wajib mengajukan pendaftaran dan perizinan kepada Otoritas Jasa Keuangan ("OJK”). Terhadap pelanggaran atas kewajiban tersebut, maka berlaku Pasal 47 ayat (1) POJK 77/2016 yang berbunyi: Atas pelanggaran kewajiban dan larangan dalam peraturan OJK ini, OJK berwenang mengenakan sanksi administratif terhadap Penyelenggara berupa: ${ }^{9}$
a) peringatan tertulis;
b) denda, yaitu kewajiban untuk membayar sejumlah uang tertentu;
c) pembatasan kegiatan usaha; dan
d) pencabutan izin.

e) Sanksi administratif berupa denda, pembatasan kegiatan usaha, dan pencabutan izin, dapat dikenakan dengan atau tanpa didahului pengenaan sanksi administratif berupa peringatan tertulis. Sanksi administratif berupa denda dapat dikenakan secara tersendiri atau secara bersama-sama dengan pengenaan sanksi administratif lainnya.

Permasalahan Penyelenggara "Ilegal" Berdasarkan keterangan yang Anda berikan, kami asumsikan istilah "ilegal" yang Anda maksud merujuk pada penyelenggara yang tidak melakukan kewajibannya untuk mendaftarkan diri dan mengajukan permohonan izin sebagaimana dimaksud dalam Pasal 7 POJK 77/2016. Patut diperhatikan bahwa perjanjian hanya berlaku bagi pihak-pihak yang membuatnya sebagaimana bunyi Pasal 1338 BW: "Semua persetujuan yang dibuat sesuai dengan undang-undang berlaku sebagai undang-undang bagi mereka yang membuatnya. Persetujuan itu tidak dapat ditarik kembali selain dengan kesepakatan kedua belah pihak, atau karena alasanalasan yang ditentukan oleh undangundang. Persetujuan harus dilaksanakan dengan itikad baik."

Sebagaimana diterangkan dalam POJK 77/2016, penyelenggara dan pemberi 
serta penerima pinjaman merupakan tiga entitas yang berbeda. Penyelenggara terbatas pada penyedia platform yang mempertemukan pemberi pinjaman dan penerima pinjaman.

Sementara itu, merujuk pula pada Pasal 18 huruf b POJK 77/2016, perjanjian pinjam meminjam yang Anda buat pada dasarnya adalah antara pemberi dan penerima pinjaman, bukan dengan penyelenggara.

Di dalam praktik, sepanjang penelusuran kami, penyelenggara kemudian bertindak sebagai kuasa dari pemberi pinjaman dalam memberikan pinjamannya kepada penerima pinjaman. Pemberian kuasa diatur dalam Pasal 1792 BW yang menerangkan bahwa: "Pemberian kuasa ialah suatu persetujuan yang berisikan pemberian kekuasaan kepada orang lain yang menerimanya untuk melaksanakan sesuatu atas nama orang yang memberikan kuasa."

Berdasarkan ketentuan tersebut, pemberian kuasa memberikan kuasa kepada penyelenggara untuk membuat perjanjian dengan penerima pinjaman atas nama pemberi pinjaman. Maka dari itu, penerima kuasa tersebut haruslah juga memenuhi unsur subjektif dalam Pasal $1320 \mathrm{BW}$.

Akibat dari ketidakberwenangan tersebut adalah tidak terpenuhinya unsur subjektif dalam perjanjian. Maka dari itu, menurut hemat kami, perjanjian yang dilakukan antara pemberi dan penerima pinjaman di saat penyelenggara pinjam meminjam uang secara elektronik berstatus tidak berizin, menjadi dapat dibatalkan. Dalam hal ini, penyelenggara tidak memenuhi unsur kecakapan akibat tidak terdaftar dan berizinnya penyelenggara tersebut.

Akibat Perjanjian Pinjam Meminjam Dibatalkan Apabila perjanjian tersebut dibatalkan, para pihak tunduk pada ketentuan Pasal 1451 BW, yang berbunyi: “ Pernyataan batalnya perikatanperikatan berdasarkan ketidakcakapan orang- orang tersebut dalam Pasal 1330, mengakibatkan pulihnya barang-barang dan orang-orang yang bersangkutan dalam keadaan seperti sebelum perikatan dibuat, dengan pengertian bahwa segala sesuatu yang telah diberikan atau dibayar kepada orang tak berwenang, akibat perikatan itu, hanya dapat dituntut kembali bila barang yang bersangkutan masih berada di tangan orang tak berwenang tadi, atau bila ternyata bahwa orang ini telah mendapatkan keuntungan dan apa yang telah diberikan atau dibayar itu atau bila yang dinikmati telah dipakai bagi kepentingannya." 


\section{REFERENSI.}

A. BUKU

Djoni S. Gozali dan Rachmadi Usman, Hukum Perbankan, cet. II, Sinar Grafika, Jakarta, 2012.

Kiko Sarwin,Dkk, Eds. Kajian Perlindungan Konsumen Sektor Jasa Keuangan:Perlindungan Konsumen Pada Fintech (Jakarta: Departemen Perlindungan Konsumen OJK, 2017.

Peter Mahmud Marzuki, Metode Penelitian Hukum. Kencana, Jakarta 2005.

R. Subekti. Hukum Perjanjian. Jakarta: Intermasa, 2014.

B. PERUNDANG -UNDANGAN

Kitab Undang-Undang Hukum Perdata;

Undang-Undang Nomor 21 Tahun 2011 tentang Otoritas Jasa Keuangan;

Peraturan Otoritas Jasa Keuangan Nomor 77/POJK.01/2016 Tahun 2016 tentang Layanan Pinjam Meminjam Uang Berbasis Teknologi Informasi;

Peraturan Otoritas Jasa Keuangan Nomor 18/POJK.03/2017 Tahun 2017 tentang Pelaporan dan Permintaan Informasi Debitur Melalui Sistem Layanan Informasi Keuangan.

\section{WEBSITE}

Ayu Lestari Wahyu Puranidhi 2019, "pinjaman online ilegal dari OJK”,https://www.liputan6.com/ me/ayu.puranidhi, Jakarta.

https://www.hukumonline.com/berita/ baca/lt5a97b394460ec/aspekhukum-fintech-di-indonesiayang-wajib-diketahui-lawyer/. https://www.hukumonline.com/klinik/ detail/ulasan/lt5d82e273126a2/hu kumnya-jika-terlilit-utang-pinjolilegal/ 